\title{
Perlindungan Hukum dan Hak Waris Istri Kedua dalam Perkawian Poligami Tanpa Izin
}

\section{Protection Law Andvinheritence Right for The Second Wife in Poligamy Meriage Without Licence Based}

\author{
Misda Deni'), Asmuni') \& T. Erwinsyahbana ${ }^{2)}$ \\ 1)Prodi Magister Kenotariatan, Fakultas Hukum \\ Universitas Muhammadiyah Sumatera Utara, Indonesia \\ 2) Prodi Ilmu Hukum, Fakultas Hukum \\ Universitas Muhammadiyah Sumatera Utara, Indonesia
}

Diterima: 01 Maret 2020; Disetujui: 12 Maret 2020; Dipublish: 23 Maret 2020

*Coresponding Email: misda.deni24@gmail.com

\begin{abstract}
Abstrak
Perkawinan poligami harus dilakukan dengan persetujuan atau izin isteri sehingga hal ini menjadikan satu permasalahan hukum baru terhadap kedudukan isteri kedua, baik dari segi hak dan kewaajiban, anak, harta dalam perkawinan serta masalah pembagian harta warisan. Tujuan penulisan ini untuk mengetahui perlindungan hukum bagi isteri kedua terhadap status hukumnya dalam perkawinan poligami dan untuk mengetahui hak waris isteri dalam perkawinan poligami menurut fikih Islam dan hukum positif. Metode penelitian penulisan ini yuridis normatif dengan jenis penelitian deskriptif analisis. Perlindungan hukum bagi isteri kedua untuk mendaoatkan hak dan pengakuan harus melakukan pengesahan pernikahan (isbat nikah) di Pengadilan Agama. Hak waris isteri kedua terhadap perkawinan poligami tanpa izin yaitu berhak atas harta waris bersama suami sejak perkawinan berlangsung dan kesemua isteri memiliki hak yang sama atas harta waris tersebut dalam 1/8 jika mempunyai anak dan $1 / 4$ jika tidak mempunyai anak.
\end{abstract}

Kata Kunci: Perkawinan, Poligami, Hak Waris

\begin{abstract}
Polygamy marriage must be done with the consent or permission of the wife so that this creates a new legal problem regarding the position of the second wife, both in terms of rights and obligations, children, assets in the marriage as well as problems in the distribution of inheritance. The purpose of this paper is to determine the legal protection of a second wife to their legal status in polygamy marriage and to find out the rights of wife's inheritance in polygamy marriage according to Islamic fiqh and positive law. This research method is normative juridical with descriptive analysis research type. Legal protection for the second wife to get the rights and recognition must legalize marriage (isbat nikah) in the Religious Court. The second inheritance right of the wife to the polygamy marriage without permission is the right to inheritance with her husband since the marriage took place and all wives have the same rights to the inheritance within $1 / 8$ if they have children and $1 / 4$ if they do not have children.
\end{abstract}

Keywords: Marriag, Polygamy, inheritance rights

How to Cite: Deni, M, Asmuni \& Erwinsyahbana, T. (2020). Perlindungan Hukum dan Hak Waris Istri Kedua dalam Perkawian Poligami Tanpa Izin. Journal of Education, Humaniora and Social Sciences (JEHSS). 2 (3): 633-643. 


\section{PENDAHULUAN}

Perkawinan merupakan suatu peristiwa sejarah dalam kehidupan manusia yang memiliki dimensi ruang dan waktu serta urgensitas yang kompleks, karena akibat dari perkawinan menimbulkan peristiwa-peristiwa bari seperti kelahiran anak, harta bersama, hukum kewarisan dan lainnya. Perkawinan merupakan sunnatullah yang berlaku secara umum dan perilaku makhluk ciptaan Allah, dengan perkawinan kehidupan di alam dunia ini bisa berkembang untuk meramaikan alam yang luas dari generasi ke generasi berikutnya (Hadikusuma, 2003).

Terdapat berbagai macam bentuk perkawinan dalam masyarakat, yang paling populer diantaranya perkawinna monogami dan poligami. Perkawinan monogami merupakan perkawinan yang paling sesuai untuk dilakukan. Poligami merupakan suatu realitas dalam perkawinan yang terjadi di masyarakat, dimana seorang laki-laki memilliki isteri lebih dari seorang. Abbas Mahmud al-Aqqad berpendapat bahwa Islam tidak menciptakan poligami, tidak mewajibkan dan tidak pula mensunnatkannya. Akan tetapi Islam mengizinkan poligami itu dalam beberapa kondisi tertentu dengan syarat keadailan dan kemampuan (Gani, 1979).

Perkawinan poligami sebagaimana yang diatur pada Pasal 5 ayat (1) UndangUndang Nomor 1 Tahun 1974 tentang Perkawinan, yang menjelaskan bahwa harus adanya persetujuan dari istri atau istri-istri dalam hal seorang suami akan beristri lebih dari seorang. Praktiknya dilapangan tidak semua perkawinan poligami dilakukan tanpa adanya persetujuan atau izin istri pertama, sehingga hal ini menjadikan satu permasalahan hukum baru terhadap kedudukan istri kedua, baik dari segi hak dan kewajiban, anak, harta dalam perkawinan, serta masalah pembagian harta warisan.

Persetujuan dari istri atau istri-istri bagi suami yang bermaksud ingin menikah lagi dengan wanita lain (berpoligami) adalah salah satu syarat untuk mengajukan permohonan izin berpoligami kepengadilan Agama (Pasal 4 ayat (1) dan Pasal 5 ayat (1) huruf a Undang-Undang Perkawinan. Selain persyaratan adanya persetujuan istri, masih terdapat dua persyaratan lagi, yaitu adanya kepastian bahwa suami yang bersangkutan mampu menjamin keperluan keperluan hidup istri dan anak-anak mereka dan adanya jaminan bahwa suami akan berlaku adil terhadap istri-istri dan anak-anak mereka (Pasal 5 ayat (1) huruf b dan c). 
Pasal 65 ayat (1) Undang-Undang Perkawinan juga menegaskan bahwa jika seorang suami berpoligami maka suami: (1) suami wajib memberi jaminan hidup yang sama kepada semua istri dan anaknya, (2) istri yang kedua dan seterusnya tidak mempunyai hak atas harta waris yang telah ada sebelum perkawinan dengan istri kedua atau berikut itu terjadi, dan (3) semua istri mempunyai hak yang sama atas harta waris yang terjadi sejak perkawinan masing-masing.

Permasalahan berikutnya adalah tentang pembagian harta warisan dalam perkawinan poligami, di mana ketika sang suami meninggal dunia, maka tanpa adanya surat nikah dan akta kelahiran, istri kedua dan anak-anak yang dilahirkan akan kesulitan untuk mengklaim bagian dari harta waris yang semestinya mereka dapatkan karena dikuasai oleh istri pertama dan karena ketiadaan bukti otentik perkawinannya, padahal istri kedua dan anak-anak yang dilahirkan dari perkawinan kedua tersebut adalah sah (Susetyo, 2007).

Tujuan dari penulisan ini adalah untuk mengetahui perlindungan hukum bagi isterri kedua terkait kedudukan dan status hukumnya dalam perkawinan poligami tanpa adanya izin, untuk mengetahui waris para isteri dalam perkawinan poligami tanpa izin menurut Fikih Islam dan hukum positif. Landasan teori dalam penelitian ini adalah teori keadilan yang tujuannya untuk memecah masalah substansi setiap sistem hukumnya dan teori perlindungan hukum. Menurut N. Quraish Shihab mengemukakan adil pada awalnya diartikan dengan sama atau persamaan, itulah yang menjadikan pelakunya tidak memihak atau berpihak pada yang benar (Asse, 2010).

Perlindungan hukum merupakan keberadaan hukum dalam masyarakat merupakan suatu sarana untuk menciptakan ketentraman dan ketertiban masyarakat, sehingga dalam hubungan antar anggota masyarkat yang satu dengan yang lainnya dapat dijaga kepentingannya (Mertokusumo, 2003).

\section{METODE PENELITIAN}

Metode penelitian dalam penulisan ini menggunakan jenis penelitian yuridis normatif, penelitian hukum normatif adalah penelitian hukum yang meletakkan hukum sebagai sebuah bangunan sistem norma mengenai asas-asas, norma, kaidah dari 
peraturan perundang-undangan, putusan pengadilan, perjanjian serta doktrinatau ajaran (Achmad, 2010).

Penelitian yang dilakukan dan ditujukan dengan menganalisis peraturan perundang-undangan, buku-buku, internet, pendapat sarjana, dan bahan lainnya. Jenis penelitian ini adalah deskriptif analisis yang merupakan metode yang dipakai untuk menggambarkan suatu kondisi atau keadaan yang sedang berlangsung yang tujuannya agar dapat memberikan data mengenai objek penelitian sehingga mampu menggali halhal yang bersifat ideal, kemudian dianalisis berdasarkan teori hukum atau peraturan perundang-undangan yang berlaku (Surakhmad, 1978).

Alat pengumpulan data yang digunakan adalah studi dokumen dan melakukan wawancara mendalam (dept interview) kepada informan yakni Hakim Pengadilan Agama Medan. Pengolahan, analisis dan konstruksi data penelitian hukum normatif dapat dilakukan dengan cara melakukan analisis terhadap kaidah hukum dan kemudian

konstruksi dilakukan dengan cara memasukkan pasal-pasal ke dalam kategorikategori atas dasar pengertian-pengertian dari system hukum tersebut (Mahmud, 2013). Teknik analisis data yang diterapkan membahas tentang keadilan dan perlindungan hukum hak waris istri kedua dalam perkawinan poligami yang dilakukan secara analisis kualitatif.

\section{HASIL DAN PEMBAHASAN}

\section{Perlindungan Hukum}

Pengadilan Agama sebagai pelaksana kekuasaan Kehakiman bagi rakyat pencari keadilan bagi yang beragama Islam mengenai perkara Perdata tertentu, berwenang mengabulkan/mengizinkan atau tidak mengabulkan/tidak mengizinkan permohonan izin poligami yang diajukan oleh seorang suami (Pasal 10 ayat (1) Undang-undang No. 14 Tahun 1970 tentang Ketentuan-ketentuan Pokok Kekuasaan Kehakiman dan Pasal 49 Undang-Undang No. 7 Tahun 1989 tentang Peradilan Agama serta Pasal 4 UU Perkawinan). Perizinan perkawinan poligami di pengadilan merupakan perkara permohonan. Pengadilan yang berwenang menetapkan izin perkawinan poligami adalah pengadilan agama. Tugas dan kewenangan peradilan agama menurut Pasal 49 UndangUndang Nomor 3 Tahun 2006 tentang Peradilan Agama yaitu memeriksa, memutus, dan menyelesaikan perkara-perkara perdata bidang perkawinan, kewarisan, wasiat, hibah 
yang dilakukan berdasarkan ajaran syari"ah, wakaf dan sedekah. Kewenangan peradilan agama tersebut berdasar atas asas personalitas keislaman, yaitu yang dapat ditundukkan ke dalam kekuasaan lingkungan peradilan agama hanya bagi umat muslim.

Perkawinan poligami apabila seorang suami bermaksud untuk beristeri lebih dari seorang maka ia wajib mengajukan permohonan secara tertulis kepada pengadilan agama. Pengadilan agama kemudian memeriksa mengenai (pasal 41 PP No. 9/1975): 1) Ada atau tidaknya alasan yang memungkinkan seorang suami kawin lagi, diantaranya bahwa isteri tidak dapat menjalankan kewajibannya sebagai isteri, bahwa isteri mendapat cacat badan atau penyakit yang tidak dapat disembuhkan dan bahwa isteri tidak dapat melahirkan keturunan; 2) Ada atau tidaknya persetujuan dari isteri, baik persetujuan lisan maupun tertulis, apabila persetujuan lisan, persetujuan itu harus diucapkan di depan sidang pengadilan; 3) Ada atau tidak adanya kemampuan suami untuk menjamin keperluan hidup isteri-isteri dan anak-anak dengan memperhatikan surat keternagan mengenai penghasilan suami, surat keternagan pajak penghasilan dan surat keternagan lain yang dapat diterima oleh pengadilan; 4) Ada atau tidaknya jaminan bahwa suami akan berlaku adil terhadap isteri-isteri dan anak-anak dengan pernyataan/janji dari suami yang dibuat dalam bentuk yang telah ditetpakan.

Islam dalam kitab sucinya mengatakan apabila seorang suami menikah lebih dari seorang maka ia diwajibkan berlaku adil terhadap isteri-isterinya dan tanggung jawab yang diamankan sepenuhnya. Sebaliknya jika mereka (suami) tidak berlaku adil terhadap isteri-isterinya maka hendaklah menikahi satu perempuan saja. Maksunya berlaku adail adalah perlakuan yang adil dalam meladeni isteri-isteri seperti pakaian, tempat, giliran dan lain-lain yang bersifat lahitiyah dan bathiniyah.

Kewajiban adanya persetujuan atau izin sang istri bagi suami yang ingin berpoligami serta adanya kepastian suami mampu menjamin keperluan hidup istri-istri dan anak-anak mereka dimaksudkan untuk melindung harkat dan martabat istri kedua. Izin harus dibuat secara hitam di atas putih, maksud untuk dibuat secara tertulis, agar adanya kepastian dan perlindungan hukum terhadap sang istri, apabila tidak bisa dibuat secara tertulis maka dapat dilakukan secara lisan, tetapi bila secara lisan maka harus dilakukan didepan pengadilan. Berdasarkani persyaratan tersebut, pada dasarnya 
undang-undang sudah melakukan langkah preventif untuk memberikan perlindungan hukum bilamana ada suami yang beritikad buruk berpoligami.

Berdasarkan hasil wawancara dengan Ibu Yeyen selaku Hakim Pengadilan Agama Medan Klas IA, menjelaskan bahwa perlindungan hukum terhadap istri kedua, ketiga, atau keempat khususnya pada perkawinan poligami yang tidak dicatatkan memang sangatlah lemah. Pemecahan masalah tersebut diatas dewasa ini dapat disikapi dengan cara mengajukan permohonan itsbat nikah poligami kepada pengadilan agama. Itsbat nikah ke pengadilan agama oleh para pemohon dijadikan alas hukum untuk mencatatkan perkawinannya kepada pegawai pencatat nikah pada Kantor Urusan Agama (KUA) Kecamatan, Kantor Urusan Agama (KUA) Kecamatan akan mengeluarkan Buku Kutipan Akta Nikah sebagai bukti autentik bahwa suatu perkawinan telah tercatat (Hasil Wawancara Dengan Ibu Yeyen, selaku Hakim Pengadilan Agama Medan Klas IA yang dilakukan pada tanggal 8 Februari 2019).

Pengadilan agama dalam mengatasi peroblema pernikahan siri yang berkembang di masyarakat saat ini bertanggung jawab dalam mengakomodir pengesahan pernikahan siri melaui upaya hukum itsbat nikah. Upaya hukum ini dapat dilakukan masyarakat yang menikah dengan cara siri, agar pernikahannya di akui oleh negara, akan tetapi perlu diketahui bahwa itsbat nikah ini hanya bisa dilakukan jika suami istri yang memohon itsbat nikah masih terikat dalam perkawinan yang sah menurut agamanya, dan jika suami istri tersebut telah bercerai maka upaya hukum itsbat nikah tidak dapat dilakukan.

Menurut penjelasan dari Ibu Rubi"ah selaku Hakim Pengadilan Agama Medan Kelas IA mengatakan bahwa sangat sulit bagi pasangan yang tidak menginginkan perceraian, selain itu proses yang akan dijalaninya pun akan memakan waktu yang lama. Mengenai tingkat keberhasilan permohonan itsbat nikah (dikabulkan atau ditolak) sepenuhnya menjadi kewenangan hakim yang menyidangkan perkaranya setelah meneliti data persyaratan yang diajukan pemohon, dan tentu saja hakim di setiap pengadilan agama berbeda dalam memberi ketetapan, dan semua dikembalikan pada hati nurani para hakim dalam memberi rasa keadilan bagi pemohon dan yang menjadi korban Hasil (Wawancara dengan Ibu Rubi"ah, selaku Hakim Pengadilan Agama Medan Klas IA yang dilakukan pada Tanggal 8 Februari 2019). 
Selanjutnya, Ibu Rubi"ah menjelaskan bahwa memahami pasal tersebut, bahwa secara umum itsbat nikah diperlukan agar perkawinan memiliki kekuatan hukum, namun prosesnya hanya dapat dilakukan ketika perkawinan siri masih berlangsung, dengan tujuan untuk mengukuhkan dan meningkatkan kualitas ikatan perkawinan itu sendiri, selain agar perkawinan tercatat dan memiliki kekuatan hukum. Itsbat nikah tidak dapat dilaksanakan ketika perkawinan sudah tidak ada, atau ketika perceraian sudah terjadi, sebab apa yang mau di itsbatkan ketika perkawinannya sendiri sudah tidak ada. Selain itu, Ibu Rubi"ah menambahkan bahwa selambatlambatnya, itsbat nikah dapat dilakukan ketika proses perceraian dimulai dan ikatan perkawinan masih ada, ketika perceraian sudah terjadi, apalagi sesudah habis masa iddah, itsbat nikah sudah tidak relevan lagi, setelah terjadi perceraian dan masa iddah sudah habis. Sementara untuk mendapatkan pengesahan anak yang dilahirkan dari perkawinan siri juga harus disertakan bersamaan dengan pengajuan itsbat nikah agar mendapat penetapan yang sama dengan pengesahan nikah orang tuanya (Hasil Wawancara dengan Ibu Rubi"ah, selaku Hakim Pengadilan Agama Medan Klas IA yang dilakukan pada Tanggal 8 Februari 2019).

Hakim dalam hal ini berperan penuh dalam menilai pengajuan perkara itsbat nikah istri poligami, di mana hakim harus membuat interpretasi yang arif, apakah perkara tersebut diajukan dari awal perkara sebagai izin poligami. Terdapat sisi negatif maupun sisi positif dari itsbat nikah ini, sisi negatifnya dimungkinkan adanya penyelundupan perkara dimana dalam mengajukan permohonan itsbat nikah tanpa melibatkan istri pertama atau istri terdahulu, namun sisi positifnya akhirnya status perkawinannya menjadi sah di mata hukum negara dengan demikian akibat hukum yang ditimbulkan pun menjadi terlindungi secara hukum negara (Hakim Rubi'ah, 2019). Berdasarkan hal tersebut maka pengabulan itsbat nikah ini kerena memperhatikan nasib anak-anak yang lahir dari perkawinan yang tidak dicatatkan (perkawinan siri) dan satu-satunya jalan adalah dengan menempuh itsbat nikah di pengadilan agama, dan jika dikabulkan maka status anak pun berubah menjadi anak sah juga. Hakim dalam menetapkan dan memutuskan perkara itsbat nikah poligami, harus memperhatikan semua hal secara objektif dengan pertimbangan yang matang. 
Hakim Rubi'ah mengatakan bahwa setiap perkawinan harus dicatatkan menurut peraturan perundang-undangan yang berlaku untuk mewujudkan ketertiban administrasi dalam hukum perkawinan, sementara untuk perkawinan yang sudah terlanjur melakukan nikah siri maka perkawinan tersebut harus disahkan dengan mengajukan itsbat nikah di pengadilan agama. Persetujuan dari osteri pertama atau terdahulu dalam itsbat nikah pada isteri poligami bukanlah suatu keharusan, jika persetujaun tidak mungkin didapatkan, hakim dengan pertimbangan tertentu dapat mengabulkan perkara itsbat nikah isteri poligami.

\section{Hak Waris}

Hukum kewarisan Islam didasarkan kepada asas ijbari dalam pengertian bahwa manusia tidak bebas memberikan tirkahnya kepada orang-orang yang dikehendakinya. Asas ijbari dalam kewarisan Islam, pewaris harus memberika dua pertiga tirkahnya kepada ahli waris, sedangkan sepertiga lainnya pewaris dapat berwasiat untuk memberikan harta waris tersebut kepada siapa yang dikehendakinya sebagai taqarrub dan mengharap pahala dari Allah SWT (Manan, 2006).

Poligami yang dilakukan tanpa memnuhi persyatratan yang telah dutentukan dalam undang-undang seperti izin dari isteri maka sang isteri dapat melakukan permohonan pembatalan perkawinan. Terakit hal waris isteri pertama dan anakanaknya dalam perkawinan poligami adalah semua harta bersama yang didapatkan oleh isteri pertama dan suaminya selama dalam masa perkawinan. Harta bersama adalah harta kekayaan yang diperoleh selama perkawinan di luar hadiah atau warisan, maksunya adalah harta yang didapat atas usaha mereka atau sendiri-sendiri selama masa ikatana perkawinan (Thalib, 1986).

Pembagian harta bersama sendiri tergantung dari kesepakatan kedua belah pihak dan sudah seharusnya suami tidak boleh mengganggu harta isteri akan tetapi suami wajib memberikan harta kepada isteri sebagai nafkahnya serta isteri mendapat harta dari suami sebagai mahar kemudian mendapat harta dari kelauarga ketika hibah atau warisan. Islam menghendaki adanya pembukuan yang rapi dan akuntabel yang dibuat oleh suami isteri yang memilikk harta bersama tersebut, sehingga tidak terjadi percampuran harta bersama isteri pertama, kedua dan seterusnya. Dengan demikian hak 
isteri pertama dalam harta bersama lebih terjamin setelah ditetapkan oleh pengadilan agama.

Ketentuan harta waris diatur dalam Pasal 65 ayat (1) Undang-Undang No. 1 tahun 1974 yang menegaskan bahwa jika seorang suami berpoligami: 1) Suami wajib memberi jaminan hidup yang sama kepada semua isteri dan anaknya; 2) Isteri yang kedua dan seterusnya tidak mempunyai hak hak atas harta waris yang telah ada sebelum perkawinan dengan isteri kedua atau berikut itu terjadi; 3) Semua isteri mempunyai hak yang sama atas harta warisan yang terkadi sejak perkawinan masing-masing.

Kedudukan harta waris isteri pertama dari suami yang berpoligami mempunyai hak atas harta waris yang dimlikinya bersama dengan suami. Isteri kedua dan seterusnya berhak atas harta waris bersama dengan suaminya sejak perkawinan mereka berlangsung dan kesemua isteri memiliki yang sama atas harta waris tersebut. Selanjutnya apabila dalam pembagian harta warus tidak dapat dilakukan secara bermusyawarah oleh para ahli waris dan terjadi perselisihannya itu diajukan kepada pengadilan agama dan penyelesaian melalui jalur pengadilan adalah sebuah pilihan.

Pelaksanaan pembagian waris berdasarkan kesepakatan melalui musyawarah lebih banyak bernilai baik daripada pembagian melalui pengadilan agar tetap terjada hubungan antar ahli waris tidak terputus dan tidak dendam dikemudian hari, untuk mendapatkan kedudukan dan status sebagai ahli waris dalam perkawinan poligami, maka perkawinan: 1)Perkawinna poligami dilakukan dengan izin isteri pertama dan harus mendapat persetujuan dari pengadilan; 2)Pengajuan persetujuan dari pengadilan harus mendapat izin dari isteri pertama; 3)Perlaksanaan perkawinan harus dilakukan dan dicatat di lembaga pencatatan perkawinan; 4)Perlunya perjanjian perkawinan sehingga bisa membedakan harta bawaan dengan harta bersama.

Berdasarkan konsep hukum fiqih terhadap hak waris isteri kedua perkawinan poligami tanpa izin haknya dan harus berbuat adil. Adil tersebut jika dihubungkan dengan teori keadilan menurut Aristoteles mengenai asas persamaan maka haru sada persamaan dalam bagian yang diterima oleh orang-orang, maka rasio dari yang dibagi harus sama dengan risiko dari orang-orangnya, sebab apabila orang-orangnya tidak sama maka disitu tidak akan ada bagian sama pula, maka apabila orang-orang yang sama 
tidak menerima bagian yang sama atau orang-orang yang tidak sama menerima bagian yang sama dan timbullah sengekta.

Pada perkawinan poligami baik dilihat dari hukum perdata, hukum adat atau dari hukum syari'ah banyak mendapat kesulitan untuk menentukan harta bersama, karena dalam perkawinan poligami yang sering terjadi dalam praktiknya sangat jarang didaftarkan pada lembaga pencatat perkawinan, karena untuk mencatatkan perkawinan poligami haruslah mendapat persetujuan dan izin dari isteri pertama dan kedua dan seterusya melalui pengadilan.

Perkawinan poligami yang tidak tercatat akan menimbulkan hambatan dikemudian hari dalam melakukan pembagian waris. Secara hukum bagi wanita yang terkait dalam perkawinan poligami dalam menuntut haknya selaku ahli waris, maka wanita (isteri kedua, ketiga dan seterusnya) yang bersangkutan harus memohon itsbat nikah melalui pengadilan agama, setelah melakukan itsbat nikah barulah kemudian yang bersangkutan dapat melakukan gugatan ungtuk ditetapkan sebgai ahli waris berikut berhak untuk mendapatkan pembagian waris sesuai dengan ketentuan hukum yang berlaku.

Berdasarkan hasil wawancara dengan Ibu Rubi'ah selaku Hakim Pengadilan Agama Medan Klas IA, menjelaskan mengenai upaya hukum bagi istri kedua dalam hal hak warisnya dikuasai oleh istri pertama dapat melakukan tindakan hukum berupa: 1)Musyawarah dengan keluarga baik keluarga istri pertama, keluarga suami dan keluarga istri kedua; 2) Menunjuk mediator dalam hal diperlukan mediator untuk menyelsaikan sengketa; 3) Istri kedua melakukan permohonan itsbat nikah ke pengadilan agama untuk melegalkan perkawinan poligaminya; 4) Setelah pernikahan poligaminya diitsbatkan ke pengadilan agama, selanjutnya istri kedua dapat mengajukan gugatan penentuan ahli waris dari suami yang telah meninggal dunia; 5) Pengadilan selanjutnya memutuskan dan menetapkan bagian harta warisan dan beserta ahli warisnya masing-masing.

Upaya yang dijelaskan oleh Hakim Rubi'ah tersebut merupakan bentuk perlindungan hukum yang diberikan kepada isteri kedua terhadap perkawinan poligami tanpa izin, maka tindakan yang dapat dilakukan isteri kedua untuk menentukan ahli waris dan harta waris terhadap suami apabila berakhirnya perkawinan abik meninggal dunia atau perceraian. 


\section{SIMPULAN}

Adapun yang menjadi kesimpulan dalam penulisan ini adalah bahwa perlindungan hukum bagi siteri kedua terkait kedudukan dan status hukumnya dalam perkawinan poligami tanpa izin adalah tujuan perlindungan hukum untuk pemecahan masalah hukum serta memlihara kepastian hukum, pada dasarnya salah satu perlindungan hukum bagi isteri kedua untuk mendapatkan hak waris dan pengakuan anak terhadap suami yang melakukan poligami yaitu melakukan itsbat nikah ke pengadilan. Hak waris isteri dalam perkawinan poligami menurut hukum fikih Islam bahwaa semua harta peninggalan berupa harta bawaan suami dan harta bersama yang didapatkan isteri dan suami selama masa perkawinan. Hak waris isteri kedua terhadap perkawinan poligami tanpa izin yaitu berhak atas harta waris bersama suami sejak perkawinan berlangsung dan kesemua isteri memiliki hak yang sama atas harta waris tersebut dalam 1/8 jika mempunyai anak dan $1 / 4$ jika tidak mempunyai anak.

\section{DAFTAR PUSTAKA}

Asse, A (2010). Konsep Adil Dalam Al-Qur'an, Al-Risalah. Volume 10 Nomor 2 Nopember

Fajar, M dan Achmad, Y. (2010). Dualisme Penelitian Hukum Normatif \& Empiris. Yogyakarta. Pustaka Pelajar

Fuady, M. (2007). Dinamika Teori Hukum, Cetakan Pertama. Jakarta. Ghalia Indonesia.

Hadikusuma, H.H. (1980). Hukum Waris Adat. Jakarta, Citra Aditya Bakti.

Manan, A. (1997). Beberapa Masalah Tentang Harta Bersama, Jakarta: Mimbar Hukum.rta: Ghalia Indonesia.

Marzuki, P.M. (2013). Penelitian Hukum (Edisi Revisi), Kencana Prenada Media. Jakarta.

Mertokusumo, S. (2003). Mengenal Hukum Suatu Pengantar. Liberty. Yogyakarta

Republik Indonesia, Peraturan Pemerintah Nomor 9 Tahun 1975 Tentang Pelaksanaan Undang-Undang Nomor 1 Tahun 1974 Tentang Perkawinan

Republik Indonesia, Undang-Undang Nomor 1 Tahun 1974 Tentang Perkawinan

Republik Indonesia, Undang-Undang Nomor 7 Tahun 1989 Tentang Pengadilan Agama

Surakhmad, W (1978). Dasar Dan Teknik Research. Transito. Bandung

Susetyo, H, (2007). "Revisi Undang-UndangPerkawinan”, Jurnal Lex Jurnalica Volume 4 Nomor 2, Jakarta. Universitas Esa Unggul.

Thalib, S. (1986). Hukum Kekeluargaan Indonesia. Jakarta. UI Pres. 